\title{
Effect of quartz powder and mineral admixtures on the properties of high-performance concrete
}

\author{
Nguyen Duc Vinh Quang, Yuriy M. Bazhenov, Olga V. Aleksandrova \\ Moscow State University of Civil Engineering (National Research University) (MGSU), \\ 26 Yaroslavskoe shosse, Moscow, 129337, Russian Federation
}

\begin{abstract}
Introduction. This study focuses on the use of silica fume partially replacing cement with $0,5,7.5,10,12.5$ and $30 \%$ constant replacement of fly ash by weight of cement in concrete. Concrete is probably the most extensively used construction material in the world. But the conventional concrete is losing its uses with time and high-performance concrete (HPC) is taking that place. HPC has superior mechanical properties and durability to normal strength concrete. Because of, the microstructure of HPC is more homogeneous than that of normal concrete (NC) due to the physical and chemical contribution of the mineral admixtures as well as it is less porous due to reduced w/c ratio with the addition of a superplasticizer. The inclusion of additives helped in improving the properties of concrete mixes due to the additional reduction in porosity of cement paste and improving the particle packing in the interfacial transition zone (between cement paste and the aggregates). In this experimental investigation the behavior of HPC with silica fume and fly ash with and without quartz powder were studied. The water-binder ratio was kept 0.3 and $20 \%$ quartz flour as partial replacement of fine aggregate for all cases.

Materials and methods. Used materials in Vietnam, as follow, Sulfate-resisting Portland cement $-\mathrm{PC}_{\mathrm{SR}} 40$ (type $\mathrm{V}$ ) of company Luks Cement (Vietnam) Limited was used in the work. Crushed granite of fraction $9.5 \ldots 20 \mathrm{~mm}$ - as coarse aggregate, Natural sand from Huong river of $0.15 \ldots 2.5 \mathrm{~mm}$ fraction with the fineness modulus of about 3.0 and quartz powder with an average particle size of $5 \ldots 10 \mu \mathrm{m}$ were used as fillers; Sika ${ }^{\circledR}$ Viscocrete ${ }^{\circledR}-151$ is a superplasticizer based on a blend of 3rd generation PCE polymers was used as a plasticizing admixture. The flg ash from Pha Lai thermal power plant and Sika silica Sikacrete ${ }^{\circledR}$ PP1 (particle size $<0.1 \mu \mathrm{m}$ ) was used as a mineral active admixture. The study of strength and technological properties of high-performance concrete was performed by using standard methods.

Results. Established by icate that, the workability and strength increase at a certain level and after that, they decline with further increase in the replacement level of silica fume is $12.5 \%$, on the basis of $30 \%$ FA replacement, the incorporation of $10 \%$ SF showed equivalent or higher mechanical properties and durability compared to the reference samples.

Conclusions. HPC consists of mineral admixtures such as silica fume and fly ash use combine quartz powder and superplasticizer helped in improving the strength and durability of concrete mixes due to the additional reduction in porosity of cement paste and an improved interface between it and the aggregate. With $30 \%$ fly ash is optimum dosage used to replacement of cement, incorporation $10 \%$ SF (by weight) and combine of partial replacement of fine aggregate by $20 \%$ quartz powder. On the other hand, a few mathematical equations can be used to derive the durability properties of concrete based on its compressive strength.
\end{abstract}

KEYWORDS: mineral admixture, fly ash, silica fume, quartz powder, superplasticizer, high-performance concrete, compressive strength, split tensile strength, flexural strength and durability of concrete

FOR CITATION: Nguyen Duc Vinh Quang, Bazhenov Y.M., Aleksandrova O.V. Effect of quartz powder and mineral admixtures on the properties of high-performance concrete. Vestnik MGSU [Proceedings of Moscow State University of Civil Engineering]. 2019; 14:1:102-117. DOI: 10.22227/1997-0935.2019.1.102-117 (rus.).

\section{Влияние кварцевого порошка и минеральных добавок на свойства высокоэффективных бетонов}

\author{
Нгуен Дык Винь Куанг, Ю.М. Баженов, О.В. Александрова \\ Наииональный исследовательский Московский государственный строительный университет \\ (НИУ МГСУ), 129337, г. Москва, Ярославское шоссе, д. 26
}

\begin{abstract}
АННОТАЦИЯ
Введение. Исследованы свойства бетонов, содержащих тонкомолотый кварцевый порошок, в качестве частичной замены (до 20 \%) мелкого заполнителя, а также микрокремнезем и топливная зола уноса в количестве, соответственно, $0,5,7,5,10,12,5$ и $30 \%$ массы цемента.

Бетон является наиболее широко применяемым строительным материалом. Постепенно обычные бетоны вытесняются высокоэффективными (ВЭБ), обладающими более высокими эксплуатационными показателями. Микроструктура ВЭБ - более плотная и однородная по сравнению с микроструктурой обычного бетона из-за химического и физического влияния тонкодисперсных минеральных добавок, пониженного водо-вяжущего отношения за счет использования водоредуцирующих суперпластификаторов, что увеличивает прочность и долговечность бетона, в том числе и из-за усиления сцепления между цементным камнем и поверхностью заполнителя.

Материалы и методы. Использованы сырьевые материалы Вьетнама. В качестве вяжущего - сульфатостойкий портландцемент $\mathrm{PC}_{\mathrm{SR}} 40$ (тип V), производства завода «Luks Семент Вьетнам». В качестве крупного заполнителя -
\end{abstract}


гранитный щебень фракции 9,5...20 мм, в качестве мелкого заполнителя - кварцевый песок реки Хыонг фракции $0,15 \ldots 2,5$ мм с модулем крупности 3,0, в качестве наполнителя - кварцевый порошок со средним размером частиц 5...10 мкм, в качестве пластифицирующей добавки - суперпластификатор Sika ${ }^{\circledR}$ Viscocrete ${ }^{\circledR}-151$. Как активную минеральную добавку применяли золу уноса теплоэлектростанции «Фалай» и микрокремнезем Sikacrete PP1 (размер частиц < 0,1 мкм). Определение фризико-механических свойств высокоэффективных бетонов проводилось с помощью стандартных методов исследования.

Результаты. Установлено, что зависимость прочности разработанных бетонов от количества тонкодисперсных минеральных добавок носит экстремальный характер. Наиболее высокий результат наблюдается при введении в бетонную смесь 30 \% золы уноса в сочетании с 10 \% микрокремнезема.

Выводы. ВЭБ, содержащий в качестве минеральных добавок микрокремнезем и золу уноса, а также тонкомолотый кварцевый порошок и суперпластификатор, обладает высокой прочностью за счет снижения пористости цементного камня и улучшения сцепления между ним и заполнителем. Оптимальным является состав, содержащий 30 \% золы уноса, 10 \% микрокремнезема и 20 \% тонкомолотого кварцевого порошка взамен части песка. Получены математические зависимости прочности бетона на сжатие от его состава.

кЛЮчЕВЫЕ СлОВА: минеральные добавки, зола уноса, микрокремнезем, кварцевый порошок, суперпластификатор, высокоэффективный бетон, прочность на сжатие, прочность на растяжение, прочность на растяжение при изгибе и долговечность бетона

Для цИтировАния: Нгуен Дык Винь Куанг, Баженов Ю.М., Александрова О.В. Влияние кварцевого порошка и минеральных добавок на свойства высокоэффрективных бетонов // Вестник МГСУ. 2019. Т. 14. Вып. 1. С. 102-117. DOI: 10.22227/1997-0935.2019.1.102-117

\section{INTRODUCTION}

High-performance concrete has the same basic ingredient but has a totally different microstructure than ordinary concrete. It has the properties like low water binder ratio, low porosity, low hygroscopic moisture, low heat of hydration, high workability, less bleeding, high strength at the early age, excellent mechanical and physico-chemical properties, higher durability and long service life in the harsh environment and chemical attack ... etc lead to reduces maintenance and repair cost and is obtained through a choose careful proportioning of its constituents, consists of select the right type and dosage of cement, low water to binder proportion, coarse and fine and aggregates, optimum percentage of mineral admixtures (silica fume and class F/C fly ash ...) and reasonable dosage of chemical admixtures (superplasticizer). On the other hand, quartz powder and fiber may be added in mixtures to have ultra-strength and ultra-ductility of concrete. In recent years, High-performance concrete is now viewed as an emerging type of construction material whose applications are growing both in volume and in diversity. It attracted worldwide attention due to the poor durability and short service life of these existing structures concrete. This type of concrete is generally used significantly increased in application various structures such as high-rise buildings, large-span bridges, prestressed concrete structures, underground construction work, large-span infrastructures tunnels, and containers for hazardous fluids or nuclear wastes ... etc.

In the present work, an experimental investigation into the influence of quartz sand powder and mineral admixtures (MAs) such as fly ash (by-products thermal power plants) and silica fume (by-products met- allurgical industries) on the engineering properties of HPC with respect to strength and durability such as sulfate resistance, resistance to cracks, permeability ... etc, containing different proportions of MAs compared with those of a control HPC mix having identical mix proportions but without MAs. On the other hand, silica fume in concrete increases its impermeability, electrical resistivity, tensile strength and will help enhancing the mechanical properties and improving the chemical durability of concrete. In addition, fly ash in concrete normally improves the workability of concrete, but the early-age strength may be reduced $[1,2]$.

The important engineering properties of concrete such as strength and durability are closely associated with its microstructure. The microstructure of concrete consists of three components, namely, hydrated cement paste, pore structure and interfacial transition zone (ITZ) between the cement paste and aggregates. Improving these three components leads to enhance mechanical strength and durability of concrete. Compared to a traditional concrete, the microstructure of HPC is more homogenous than, because of HPC contains both pozzolanic and chemical admixtures lead to optimizing particles distribution to obtain high density, the empty spaces in cement paste and the interface between it with the aggregates was improved by use, superplasticizer to decrease water to binder ratio (the water can be lessened about $30 \%$ ) but at the same time also help mineral admixtures acting as a fine filler such as FA, SF and quartz powder to be well dispersed in the concrete mix (filler effect). In addition, on chemically, FA and SF are common mineral admixtures used in developing HPC mix, when it is added in the concrete mixture enhances the workability of binary blended cement with silica fume alone [3-5] initially no reaction 
takes place and it remains inert, it only starts reacting with each other when the presence of cement and water in the mix, cement hydration occurs first to produce two different chemical compounds are $3 \mathrm{CaO} \cdot \mathrm{SiO}_{2}$. $3 \mathrm{H}_{2} \mathrm{O}\left(\mathrm{C}_{3} \mathrm{~S}_{2} \mathrm{H}_{3}\right.$ - calcium silicate hydrate compound is responsible for strength producing crystallization, the second compound is by-product $\mathrm{Ca}(\mathrm{OH})_{2}(\mathrm{CH}$, form free lime). Then amorphous silica in the FA and $\mathrm{SF}$ composition starts to react with $\mathrm{CH}$ (react consume lime) producing additional form calcium silicate hydrate (C-S-H) [6-8] in many of the voids around hydrated cement particle, makes denser C-S-H gel, fill the interstitial pores reducing the pore connectivity (cause pore blockage) and the microstructure porosity. Process hydration of cement $2 \mathrm{C}_{3} \mathrm{~S}+6 \mathrm{H} \rightarrow \mathrm{C}_{3} \mathrm{~S}_{2} \mathrm{H}_{3}+3 \mathrm{CH}$; $2 \mathrm{C}_{2} \mathrm{~S}+4 \mathrm{H} \rightarrow \mathrm{C}_{3} \mathrm{~S}_{2} \mathrm{H}_{3}+\mathrm{CH}$ then reacts between $\mathrm{SiO}_{2}$ with $\mathrm{CH}$ liberated by the hydrolysis of $\mathrm{C}_{3} \mathrm{~S}$ and $\mathrm{C}_{2} \mathrm{~S}$ to converts all or most of the liberated $\mathrm{CH}$ to $\mathrm{C}-\mathrm{S}$ $\mathrm{H}$ takes place according to the following equations $3 \mathrm{CH}+2 \mathrm{~S} \rightarrow \mathrm{C}_{3} \mathrm{~S}_{2} \mathrm{H}_{3}$ or $\mathrm{xS}+\mathrm{yCH}+\mathrm{zH} \rightarrow \mathrm{C}_{\mathrm{y}} \mathrm{S}_{\mathrm{x}} \mathrm{H}_{z+y}$ or according to the following reactions, the first

$\mathrm{SiO}_{2}($ solid $)+2 \mathrm{H}_{2} \mathrm{O}$ (liquid) $\rightarrow \mathrm{H}_{4} \mathrm{SiO}_{4}$ (aqueus), next

$\mathrm{H}_{2} \mathrm{SiO}_{4}$ (aqueous) $+\mathrm{nCa}^{2+}$ (aqueous) +

$+2 \mathrm{nOH}^{-}$(aqueous) $\rightarrow \mathrm{nCaO} \cdot \mathrm{SiO}_{2} \cdot(\mathrm{n}+2) \mathrm{H}_{2} \mathrm{O}$ and

last $\mathrm{SiO}_{2}($ solid $)+\mathrm{nCa}^{2+}$ (aqueous) +

$+2 \mathrm{nOH}^{-}$(aqueous) $\rightarrow \mathrm{nCaO} \cdot \mathrm{SiO}_{2} \cdot \mathrm{nH}_{2} \mathrm{O}$.

On physical, Silica fume is a by-product of silicon and ferro-silicon industries, size particles are extremely fine (particle size $<0.1 \mu \mathrm{m}$ ), it is a powder with particles having diameters 100 times smaller particles than of cement, and fine grains can fit into the space between cement grains in the same way as sand can fill the space between coarse aggregates $[9,10]$.

He Zhimin et al. (2012) [11] studied the capillary absorption of concrete by adding silica fume and fly ash in concrete mixes. The replacement levels of fly ash and silica fume were kept at 15 and $10 \%$, respectively. The authors observed that the capillary absorption of concrete decreased with the addition of silica fume. As silica fume is very fine, pores in the bulk paste or in the interfaces between aggregate and cement paste is filled by these mineral admixtures.

Sadaqat Ullah Khan et al. (2014) [12] studied the "Effects of different mineral admixtures on the properties of fresh concrete", the paper presents a review of the properties of fresh concrete including workability, heat of hydration, setting time, bleeding, and reactivity by using mineral admixtures FA, SF, GGBS, metakaolin (MK), and rice husk ash (RHA). Comparison of normal and high-strength concrete in which cement has been partially supplemented by mineral admixture has been considered. From the results study has been concluded that mineral admixtures may be categorized into two groups: chemically active mineral admixtures and micro-filler mineral admixtures. Chemically active mineral admixtures decrease workability and set- ting time of concrete but increase the heat of hydration and reactivity. On the other hand, micro-filler mineral admixtures increase workability and setting time of concrete but decrease the heat of hydration and reactivity. In general, small particle size and higher specific surface area of mineral admixture are favourable to produce highly dense and impermeable concrete. However, they cause low workability and demand more water which may be offset by adding effective superplasticizer. Silica fume and fly ash are common mineral admixtures used in developing high performance concrete mix. Silica fume as its size is smaller than cement grains, fills the voids in between the cement grains. This leads to a decrease in water demand. But its high specific area increases the water demand. Combination of these two effect results in net increase in water demand compared to normal strength concrete for a given level of workability. Super plasticizer is used to reduce the water demand. This also help the silica fume to be well dispersed in concrete mix. Mineral admixtures in concrete mix affect the physical arrangement of the system, particularly near the aggregate surface where porosity exists [13].

Perumal\& Sundararajan (2004) [14] observe the effect of partial replacement of cement with SF on the strength and durability properties of high-grade concrete. Strength and durability properties for M60, M70 and M11 0 grades of HPC trial mixes and to arrive at the maximum levels of replacement of cement with SF, investigations were taken. The strength and durability characteristics of these mixes are compared with the mixes without SF. Compressive strengths of $60 \mathrm{~N} / \mathrm{mm}^{2}$, $70 \mathrm{~N} / \mathrm{mm}^{2}$ and $110 \mathrm{~N} / \mathrm{mm}^{2}$ at 28 days were obtained by using $10 \%$ replacement of cement with SF. The results also show that the SF concretes possess superior durability properties.

Amudhavalli and Mathew (2012) [15] observe the effect of silica fume on the durability characteristics and strength of concrete. The main parameter investigated in this study is design concrete M35 grade with different cement replacement levels at $0,5,10,15$ and $20 \%$ of silica fume by weight. A detailed experimental study in compressive strength, split tensile strength, flexural strength at age of 7 and 28 day was carried out. Results shows that silica fume in concrete has improved the performance of concrete in strength as well as in durability aspect.

Jain and Pawade (2015) [16] studied the characteristics of silica fume concrete. In experimental program, six different concrete mixture were cast and tested with different cement replacement levels at $0 \%$ (control mix), 5, 10, 15, 20, and $25 \%$ of silica fume with and without super-plasticizer, constant water to binder ratio for all mix. To study physical properties of high strength silica fume concretes and their sensitivity to curing procedures in chemical environments of sulphate compounds, various kinds of acids, calcium chloride and ammonium nitrate. Durability its was evaluated, 
and then compare to a traditional concrete. This study has shown that

Sung Won Yoo et al. [17] evaluated autogenous shrinkage in HPC $(\mathrm{W} / \mathrm{B}=0.3)$ with mineral admixtures fly ash $(0,10,15,20,30 \%)$ and silica fume $(0,5,7.5$, $10,15 \%) \&$ chemical admixture shrinkage reducing agent and expansion agent. The autogenous shrinkage (AGS) in HPC with fly ash was decreased continuously with larger fly ash replacement. AGS in HPC with silica fume was increased compared to that in OPC concrete. Use of both admixtures in adequate amount can provide decrease in AGS as well as improvement of the strength.

Salim Barbhuiya et al. (2016) [18], studied the effects of silica fume on compressive strength, splitting tensile strength, resistance against chloride penetration and water absorption of concrete. Results indicated that the use of silica fume in concrete increased the compressive strength of concrete. Increase in water-binder ratio reduced the compressive strength of concrete irrespective of the use of silica fume. Silica fume had no noticeable effect on the splitting tensile strength of concrete. The resistance against chloride ion penetration increased with the increase in the contents of silica fume in concrete. A reduction in water-binder ratio (from 0.35 to 0.30 ) increased the ability of the concrete to resist chloride ion's penetration. The introduction of silica fume in concrete reduced the water absorption capacity of concrete. A change in water-binder ratio also dramatically reduced the water absorption of concrete.

In study Kannan's (2017) [19], the water-cement ratio $(\mathrm{w} / \mathrm{c})$ adopted is 0.30 , content cement is 571.57 $\mathrm{kg} / \mathrm{m}^{3}$ and with $0,5,7.5 \%$ and $10 \%$ replacement of silica fume and $10 \%$ constant replacement of Fly ash to study the mechanical properties. Results indicated that fresh concrete mixture holds both fly ash and silica fume is less prone to segregation and more cohesive, due to superplasticizer used to in the mix was helping particles fly ash and silica fume to be well dispersed in the concrete mix. The superplasticizer demand for concrete containing SF and FA increases with increasing amount of SF and FA. From the experimental results, it is evident that the compressive strength of HPC containing $7.5 \%$ of silica fume is $12.18 \%$ higher than the normal concrete. The split tensile strength of HPC containing $7.5 \%$ of silica fume is $17.06 \%$ higher than the normal concrete. Also, the flexural strength of HPC containing $7.5 \%$ of silica fume is $29.8 \%$ higher than the normal concrete. It is found that as the compressive strength of concrete gradually increase follow its age. The strength of Silica fume concrete attains high than when using both silica fume and fly ash in the concrete mixture. Durability test indicates that when more pozzolanic material is added to concrete, the water absorption will reduce.

At the current, the country Vietnam has 21 operational thermal power plants, Vietnam thermal power plants generated up to 12.2 million tonnes of coal ash every year, while one year treating only 4 million tonnes, meaning inventory rose to 25.2 million tonnes, according to the Department of Industrial Safety and Environment (DISE) under the Ministry of Industry and Trade (Vietnam). The amended master plan for electricity development for the 2011-2020 period with a vision to 2030 says that 52 coal-fired power plants will be in operation by 2030 with a total designed capacity of $52.252 \mathrm{MW}$. To produce $1 \mathrm{kWh}$ of electricity using coal dust, from 0.9 to $1.5 \mathrm{~kg}$ of coal ash will be emitted. Thus, coal ash generated annually from the 23 operational thermal power plants measures about 12.2 million tonnes. The north of the country is home to 60 per cent of the plants, while the central region has 21 per cent and the south 19 per cent. However, to date, only 17 percent of the slag and ash of the plant has been consumed, while the remaining is put on the plant's slag ground. The amount of untreated coal ash is expected to reach 61 million tons by 2018,109 million tons by 2020 , up to 248 million tons by 2025 , and 422 million tons by 2030s [20, 21]. Le Van Thien et al. (2016) [22], in study evaluated some physico-chemical and mineralogical properties, for fly ashes from three thermal power stations namely Pha Lai, Mong Duong and Ninh Binh in Northern Vietnam. Results study show that chemical composition of fly ash samples taken from thermal power plants in Vietnam is fly ash F type according to standard ASTM and GOST 25818-2017.

In recent studies, many researchers found that the use of additional cementitious materials like FA in concrete is economical and reliable. Almost shape of fly ash particles is totally spherical, allowing them to be well dispersed (flow and blend freely) in mixtures. That good capability is one of the properties making FA a desirable admixture for HPC [23-26]. Fly ash may have beneficial effects on both the fresh and hardened properties of concrete mixtures, the use of FA in concrete has proven to improve workability and long-term strength, reduce permeability, minimize risk of alkali silica reaction, lowering heat of hydration in mass concrete, and enhancing durability performance (resistance to chloride and sulphate attack) [27-30]. To avoid the pollution and reuse the waste material, the present study is carried out. As the properties are as good as the cement, the Class F fly ash (coal fly ash) and silica fume is used as fine partial replacement in the cement concrete [31].

In Vietnam, quartz sand is the most abundant element on the earth's surface and in the form of silica is consumed in a great number of industrial uses, in glass manufacture and the most used is in normally construction material. However, quartz powder (with content $\mathrm{SiO}_{2}>99.8 \%$ and size 5-20 $\mu \mathrm{m}$ ) able has many industrial applications in abrasives and polishes, in glass manufacture, fillers and extenders, silica brick manufacture, as a catalyst, in speciality coatings, cleansers, ceramics, electronics, optics, semi, refractories and speciality coatings, ultra-high or high-performance con- 
crete ... etc. to date has not been paid attention study to application them. The addition of quartz powder with ultra-fine particles improves the concrete properties for various reasons:

1. Physical effect: as far as fillers affect the concrete based on their size and shape, quartz powder can densify and homogenize the paste so it has a positive effect in fresh state and also hardened state of concrete due to its fine particles. Quartz powder in low temperature is a non-reactive additive and acts just as filler [32]. And in fresh state supplementary materials may retard the high strength concrete setting time [33].

2. Surface chemical effect: when the particles add and improve hydration by acting as a part of paste and make more specific area [34]. And for sure, by adding quartz in presence of some SF, a new grain size between SF grain sizes and cement grain sizes will fill the holes specially when quartz crushed powder particles distributed homogeneously [35].

3. Chemical effect: when the particles add and react with calcium hydroxide in the cement and make calcium silicate (surface area is the most important factor in quartz powder particles so they should be finer than 5 micron to act as a pozzolan in concrete). But in this step the quartz powder needs autoclave cure with above 90 ${ }^{\circ} \mathrm{C}$ temperature to react as a pozzolan [35], which is not realistic in huge amounts of concrete like foundations or columns in buildings.

Alaa M. Rashad said that replacing quartz powder by cement without silica fume did not change the strength of hardened concrete even with $30 \%$ replacement and just increased the slump of fresh paste, and the hydration in early ages [36]. But in the other research, Q. Yang et al. concluded that quartz powder does not help flexural strength so much, but it improves compressive strength and micro structures and adding mineral admixture such as crushed quartz can increase fire resistance in concrete [37]. But quartz powder can have a big problem in replacing for cement, which is hazardous alkali-silica reaction that can identify as the most important problem in many structures. Alkali silica reaction (ASR) means a reaction between silicon dioxide $\left(\mathrm{SiO}_{2}\right)$ and alkalis ( $\mathrm{K}$ or $\mathrm{Na}$ ) which are available in cement paste, in water saturated condition, producing an amorphous silica gel. This silica gel can react with water and because of reaction expansion will occurs, so surrounding concrete will jeopardize [38].

Pustovgar A.P. et al. (6/2018) studied the influence of quartz flour on the technological properties of selfcompensating concrete (SCC) mixtures. In this investigation, the granulometric composition of quartz flour applied in of self-compacting concrete mixtures including both two type particle size is 17 and $34 \mu \mathrm{m}$, dosage of them used to at different levels is 50 and $100 \mathrm{~kg} / \mathrm{m}^{3}$ combined with the superplasticizer additive content at levels is 2, 4, 6 and 8 liter $/ \mathrm{m}^{3}$, while dosage water is maintained at 180 liters for all mixtures. But if users type more coarse quartz flour, the increase to the dos- age of the superplasticizer causes a more pronounced rise in the mobility of the concrete mixture, on the contrary increasing the dosage of quartz flour leads to decrease the delamination of SCC. Results experimental investigations shown that with varying dosages of quartz flour and superplasticizer can be obtained SCC all classes of workability from SF1 $(550 \ldots 650 \mathrm{~mm})$ to $\mathrm{SF} 3(760 \ldots 850 \mathrm{~mm})$ and resistance to delamination (SR1, SR2), provided the correct selection of the granulometric composition of the micro filler. On the other hand, use of quartz flour D50 = 34 microns leads to insufficient optimization of the granulometric composition of the SCC and, as a consequence, the stratification of the mixture at its low mobility, while a thinner fraction D50 $=17$ microns, of the same type of micro-filler allows to obtain self-compacting concrete resistant to delamination of any classes of workability by varying the dosages of both the microfiller and the superplasticizer additive [39]. And in different research of A.P. Pustovgar et al. (2018) studied the influence of Silver bond quartz flour of grades 15 (average particle size $17 \mu \mathrm{m}$ ) and 20 (particle size $21 \mu \mathrm{m}$ ) on the physical, mechanical and operational characteristics of self-compacting concrete with partial replacement of Portland cement, as well as the study of the possibility of using various types of steel fibers and in different dosages to improve the physical, mechanical and performance properties concrete with quartz flour. The use of Silver bond quartz flour in the design of self-compacting concrete compositions. Experimental studies have shown the use of quartz flour Silverbond grades 15 and 20 allows you to design the compositions of self-compacting concrete (SCC) with different physical, mechanical and operational characteristics at specified process parameters. Thus, in the present work was the experimental the compositions of the SCC classes of workability SF1 and SF2, in terms of resistance to the segregation of concrete mix SR2, compressive strength B30-B50, tensile strength in bending $\mathrm{B}_{\mathrm{tb}} 3.6 \ldots 5.6$, with marks on frost resistance F200-F500 and waterproofing W8W18. The characteristics of the SCC using quartz flour can be further improved by introducing a steel fiber into their composition. In this study, the possibilities of increasing the compression strength class from B45 to $\mathrm{B} 55$, the bending tensile strength from $6.4 \mathrm{MPa}$ to 23.7 MPa, the frost resistance grade from F300-F600 and the water resistance grade from W10 to W20 were shown. Thus, the possibility of successful application of quartz flour of Silverbond grades 15 and 20 for the development of SCC compositions with specified characteristics was experimentally confirmed [40].

\section{MATERIALS AND METHODS}

The methodology adopted comprised of both preliminary and experimental investigations carried out using the study material and these are presented as follows. 


\section{Preliminary investigations}

In this study, the industrial wastes such as silica fume and fly ash are used as supplementary cement replacement materials. For the preliminary investigations, silica fume, fly ash, quartz powder and cement were subjected to physical and chemical analyses to determine whether they are in compliance with the standard used. In this experimental programme, the concrete was proportioned to target a mean strength of $80 \mathrm{MPa}$ with and without have mineral admixtures for testing strength and durability characteristics of concrete. The replacement different levels of sulfateresisting Portland cement by SF selected as $0 \%$ (controlled mix) 5, 7.5, 10, and $12.5 \%$ while FA selected constant replacement is $30 \%$ in the majority of cases, respectively. In addition, different materials like aggregates, quartz powder, and water to binder ratio of 0.3 , superplasticizer have been added at constant values for all mix. According to standard Vietnam, the specimen of standard cubes $(150 \times 150 \times 150 \mathrm{~mm})$ use test compressive strength, specimen cylinders $150 \times 300 \mathrm{~mm}$ used to test split tensile strength, and specimen prisms of $(100 \times 100 \times 500) \mathrm{mm}$ used to test flexural strength... etc. The other materials used are listed as follow.

\section{Materials}

In this research, sulfate-resisting Portland cement - $\mathrm{PC}_{\mathrm{SR}} 40$ (type V) of company Luks Cement (Vietnam) Limited, all properties of cement conforming to standards TCVN 7711-2013 ${ }^{1}$ and GOST 22266$2013^{2}$. The physical properties of the cement used including compressive strength at 3 days $(25.7 \mathrm{MPa})$ and 28 days $(46.5 \mathrm{MPa})$, initial setting time 170 minute and final setting time 213 minute, content $\mathrm{C}_{3} \mathrm{~A}$ is $2.49 \%$ and content $\mathrm{C}_{4} \mathrm{AF}+2 \mathrm{C}_{3} \mathrm{~A}$ is $21.23 \%$, specific gravity of cement $3.15 \mathrm{~g} / \mathrm{cm}^{3}$ and Sulfate resistance 14 days expansion is $0,016 \%$ and chemical composition of cement as listed in table 2 below.

Silica fume (SF) as mineral admixture in dry densified form obtained from Sikacrete ${ }^{\circledR}$ PP1 - Sika limited Vietnam, have particle size $<0.1 \mu \mathrm{m}$ and specific gravity approximate $2.15 \mathrm{~g} / \mathrm{cm}^{3}$ conforming to TCVN

TCVN 7711-2013. Sulfate resistant blended portland cements.

2 GOST 22266-2013. Sulphate-resistant cements. Specifications.

Table 1. Properties of mineral admixtures

\begin{tabular}{l|c|c}
\hline \multicolumn{1}{c|}{ Property } & Silica fume & Fly ash \\
\hline $\mathrm{SiO}_{2}$ Content & 92.48 & 57.43 \\
\hline Specific surface, $\mathrm{m}^{2} / \mathrm{kg}$ & 15000 to 30000 & $\sim 20000$ \\
\hline Specific gravity & 2.15 & $2.72 / 2.4$ \\
\hline Unit weight, $\mathrm{kg} / \mathrm{m}^{3}$ & 245 & 990 \\
\hline Bulk density, $\mathrm{kg} / \mathrm{ltr}$ & $0.50-0.70$ & $2.19-2.56$ \\
\hline Particle size, $\mu \mathrm{m}$ & $<0.1$ & $1-8$
\end{tabular}

Table 2. Chemical composition of cement, quartz powder and mineral admixtures

\begin{tabular}{c|c|c|c|c}
\hline Component, $\%$ & Quartz powder & Silica fume & Fly ash & ${\text { Cement } \mathrm{PC}_{\mathrm{SR}} 40}$ \\
\hline $\mathrm{SiO}_{2}$ & 99.7 & 92.48 & 57.43 & 20.59 \\
\hline $\mathrm{Al}_{2} \mathrm{O}_{3}$ & 0.044 & 0.86 & 24.05 & 3.77 \\
\hline $\mathrm{Fe}_{2} \mathrm{O}_{3}$ & 0.040 & 1.91 & 6.06 & 5.06 \\
\hline $\mathrm{CaO}$ & 0.052 & 0.32 & 0.68 & 1.72 \\
\hline $\mathrm{MgO}$ & 0.036 & 0.85 & 0.96 & 0.63 \\
\hline $\mathrm{K}_{2} \mathrm{O}$ & 0.0067 & 1.22 & 3.60 & 0.135 \\
\hline $\mathrm{Na}_{2} \mathrm{O}$ & 0.020 & 0.38 & 0.27 & 0.12 \\
\hline $\mathrm{TiO}_{2}$ & 0.044 & - & 0.70 & - \\
\hline $\mathrm{P}_{2} \mathrm{O}_{5}$ & - & - & 0.11 & - \\
\hline $\mathrm{ZrO}_{2}$ & - & - & 0.03 & - \\
\hline $\mathrm{Cr}_{2} \mathrm{O}_{3}$ & - & - & 0.02 & - \\
\hline $\mathrm{CuO}_{\mathrm{ZnO}}$ & - & - & 0.02 & 1.89 \\
\hline $\mathrm{BaO}_{\mathrm{SO} O}$ & - & - & 0.03 & 2.0 \\
\hline $\mathrm{L} . \mathrm{O} . \mathrm{I}$ & - & 0.3 & - & - \\
\hline
\end{tabular}


8827-2011 ${ }^{3}$ and GOST P 56592-2015 4 , was used. Its properties are shown in table 1,2 .

Fly ash (FA) is a by product of the thermal power plants. Fly ash normally produced from burning anthracite or bituminous coal. Class F fly ash was supplied from thermal power plants Pha Lai (Vietnam), rounded to angular in shape and have a high content of $\mathrm{CaO}$ and exhibit Pozzolonic properties, conformed to TCVN $10302-2014^{5}$ and GOST $25818-2017^{6}$. Its properties are shown in table 1, 2.

Aggregates. All the coarse aggregates used in this research work were obtained from crushed granite rock from Ga Loi stone-pit in Central region of Vietnam, coarse aggregates with nominal maximum size of aggregates as $20 \mathrm{~mm}$ in proportions of $60 \%$ and $10 \mathrm{~mm}$ in proportions of $40 \%$, with specific gravity of $2.68 \mathrm{~g} /$ $\mathrm{cm}^{3}$, volume of coarse aggregates is $2.63 \mathrm{~g} / \mathrm{cm}^{3}$, water absorption $0.5 \%$, fineness modulus of about $(6,5 \ldots 6,8)$ average strength 105.6 MPa were used. Natural sand from Huong river in central region of Vietnam with specific gravity of $(2.6 \ldots 2.65) \mathrm{g} / \mathrm{cm}^{3}$, water absorption $1 \%$, fineness modulus (FM) of about 3.0 was used as fine aggregate. The sand and coarse aggregate used for locally available in the market and usual materials used conforming to standards of TCVN 7570-2006 ${ }^{7}$, GOST 8736-2014 ${ }^{8}$ and GOST 8267.0-979.

TCVN 8827-2011. Highly activity puzzolanic admixtures for concrete and mortar - Silica fume and rice husk ash.

4 GOST R 56592-2015. Mineral admixtures for concretes and mortars. General specifications.

5 TCVN 10302-2014. Activity admixture - Fly ash for concrete, mortar and cement.

6 GOST 25818-2017. Thermal plant fly-ashes for concretes. Specifications.

TCVN 7570-2006. Aggregates for concrete and mortar Specifications.

8 GOST 8736-2014. Sand for construction works. Specifications.

9 GOST 8269.0-97. Mauntainous rock road-metal and gravel, industrial waste products for construction works. Methods of physical and mechanical tests.

The quartz powder $\left(Q_{p}\right)$ used in this study is a form of white powdered quartz flour, which replaces partial fine aggregate. The particle size used ranges from 5 to $10 \mu \mathrm{m}$, Quartz powder is milled from local silica white sand in the Central region of Vietnam. (Grind quartz sand into powder).

Superplasticizer (chemical admixture) used in this study is Sika $^{\circledR}$ ViscoCrete ${ }^{\circledR}-151$ is a high performance concrete superplasticiser based on a blend of 3rd generation PCE polymers. Density 1.075...1.095 $\mathrm{kg} /$ liter and $\mathrm{pH}$ Value 4.0...6.0. Sika $^{\circledR}$ ViscoCrete $^{\circledR}-151$ meets the requirements of TCVN 8826-2011/2 (ASTM C494 Type G) and GOST P 56592-2015 ${ }^{11}$.

The potable water is used for making concrete mixtures and curing specimens concrete and the amount of water needed for the mix can be adjusted based on the absorption of aggregate, confirming to TCVN 4506$2012^{12}$ and GOST 23732-2011 ${ }^{13}$.

\section{Mix Proportioning}

The HPC mix design in this study was proportioned to attain the strength of $80 \mathrm{MPa}$ as per the guidelines specified in standards TCVN 10306-2014 "High strength Concrete - Proportional design with cylinder sample"14, also conforming to GOST 10181-2014 ${ }^{15}$ and GOST P 57345-2016 ${ }^{16}$. A constant volume unit $\left(1 \mathrm{~m}^{3}\right)$ of mortar was chosen as a common basis. When mineral

\footnotetext{
10 TCVN 8826-2011 (ASTM C494, Type G). Chemical additives for concrete.

11 GOST 24211-2008. Admixtures for concretes and mortars.
} General specifications.

12 TCVN 4506-2012. Water for concrete and mortar. Technical specification.

13 GOST 23732-2011. Water for concrete and mortar. Technical conditions.

14 TCVN 10306-2014. High strength Concrete - Proportional design with cylinder sample.

15 GOST 10181-2014. Concrete mixtures. Methods of testing.

16 GOST P 57345-2016/EN 206-1:2013. Concrete. General specifications.

Table 3. Details of mix proportions of High-performance concrete (HPC)

\begin{tabular}{|c|c|c|c|c|c|c|c|c|c|c|c|c|c|c|c|c|}
\hline \multirow{3}{*}{ 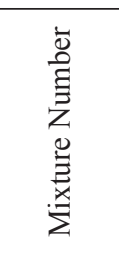 } & \multicolumn{5}{|c|}{$\begin{array}{l}\text { Supplementary cementitious } \\
\text { materials, } \mathrm{kg} / \mathrm{m}^{3}\end{array}$} & \multicolumn{6}{|c|}{ Aggregates, $\mathrm{kg} / \mathrm{m}^{3}$} & \multirow{3}{*}{$\begin{array}{c}\dot{\bar{v}} \\
\bar{\omega} \\
\dot{\xi} \\
\text { liter }\end{array}$} & \multirow{2}{*}{\multicolumn{2}{|c|}{$\begin{array}{l}\text { Super plas- } \\
\text { ticizer }\end{array}$}} & \multirow{3}{*}{$\begin{array}{c}(\mathrm{W}+\mathrm{SP}) \\
/ \mathrm{B} \\
\\
\mathrm{W} / \mathrm{B}\end{array}$} & \multirow{3}{*}{ 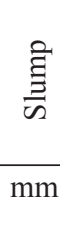 } \\
\hline & \multirow{2}{*}{$\begin{array}{c}\begin{array}{c}\text { Cement } \\
\mathrm{PC}_{\mathrm{CR}} 40\end{array} \\
\mathrm{~kg}\end{array}$} & \multicolumn{2}{|c|}{ Silica fume } & \multicolumn{2}{|c|}{ Fly ash } & \multicolumn{2}{|c|}{ Coarse agg. } & \multirow{2}{*}{$\begin{array}{c}\begin{array}{c}\text { Fine } \\
\text { agg. }\end{array} \\
\mathrm{kg}\end{array}$} & \multicolumn{3}{|c|}{$\begin{array}{l}\text { Quartz sand } \\
\text { powder }\end{array}$} & & & & & \\
\hline & & $\%$ & $\mathrm{~kg}$ & $\%$ & $\mathrm{~kg}$ & $\mathrm{~kg}$ & $\mathrm{C} / \mathrm{F}$ & & $\%$ & $\begin{array}{c}5 \\
\mu \mathrm{m}\end{array}$ & $\begin{array}{c}10 \\
\mu \mathrm{m}\end{array}$ & & $\%$ & liter & & \\
\hline S1(M0) & 550 & - & - & - & - & 1088 & 1.75 & 621.7 & - & - & - & 156 & 1.8 & 9.9 & 0.3 & 95 \\
\hline S2(M1) & 550 & - & - & - & - & 1088 & 1.75 & 497.4 & 10 & 62.2 & 62.2 & 156 & 1.8 & 9.9 & 0.3 & 230 \\
\hline S3(S1) & 412.5 & 5.0 & 27.5 & 20 & 110 & 1088 & 1.75 & 621.7 & 0 & 0 & 0 & 156 & 1.8 & 9.9 & 0.3 & 245 \\
\hline S4(M2) & 412.5 & 5.0 & 27.5 & 20 & 110 & 1088 & 1.75 & 497.4 & 10 & 62.2 & 62.2 & 152 & 1.8 & 9.9 & 0.3 & 250 \\
\hline S5(M2) & 357.5 & 5.0 & 27.5 & 30 & 165 & 1088 & 1.75 & 497.4 & 10 & 62.2 & 62.2 & 156 & 1.8 & 9.9 & 0.3 & 260 \\
\hline S6(M7) & 343.8 & 7.5 & 41.3 & 30 & 165 & 1088 & 1.75 & 497.4 & 10 & 62.2 & 62.2 & 156 & 1.8 & 9.9 & 0.3 & 265 \\
\hline S7(M6) & 330.0 & 10 & 55.0 & 30 & 165 & 1088 & 1.75 & 497.4 & 10 & 62.2 & 62.2 & 156 & 1.8 & 9.9 & 0.3 & 265 \\
\hline S8(M12) & 316.3 & 12.5 & 68.8 & 30 & 165 & 1088 & 1.75 & 497.4 & 10 & 62.2 & 62.2 & 156 & 1.8 & 9.9 & 0.3 & 230 \\
\hline
\end{tabular}


admixtures were added to this unit, then an equal volume of another component, either cement or aggregate, was removed to keep the same total volume and the common comparison basis. For this study totally eight HPC mixes were prepared with a water to binder $(\mathrm{W} /(\mathrm{C}+\mathrm{SF}+\mathrm{FA})$ ratio of 0.3 including $1.8 \%$ of superplasticizer and $20 \%$ quartz flour as partial replacement of fine aggregate were kept constant for all cases. Eight concrete mixtures with combination of both FA and SF replacement was used, different proportions of silica fume replacement at levels $0 \%$ (for the control mix), 5, 7.5, 10 and 12.5 percent while proportions of FA replacement at levels 0 (control mix) 20 and 30 percent of the mass of control cement. The proportions of constituent materials for the mixes were calculated and presented in table 3 .

\section{Casting and curing of test specimens}

The dry materials mixture is kneaded for $2 \mathrm{~min}$ utes, then the water containing the superplasticizer with dosage tantamount $1.8 \%$ by weight of binder was added in the mix, then continued for a further 3 minutes. After 5 minutes in laboratory drum mixer with amplitude of environment temperature variation ranging from $28-30^{\circ} \mathrm{C}$. For all mixes, eight cube specimens of $150 \mathrm{~mm}$ size were cast from each mix for compressive strength testing. The cylindrical specimens of 150 $\mathrm{mm}$ diameter and $300 \mathrm{~mm}$ height were also cast from each mix for determining the splitting tensile strength and beam specimen of size $100 \times 100 \times 500 \mathrm{~mm}$ were prepared for the flexural strength test. After casting, all freshly cast specimens were left in the demoulding for 24 hours before being demoulded and then submerged in water for curing until the time of testing at ages 3 , 7, 28 and 56 days such as in fig. 1, specimens were air dried and then tested for its compressive strength, split tensile and flexural strength and durability of concrete as per Vietnam standards, conforming to GOST 10180$2012^{17}$ and GOST 31384-2017 18 and СП 28.13330$2017^{19}$. Table 4 shows the number of specimens cast and the testing arrangement.

17 GOST 10180-2012. Concretes. Methods for strength determination using reference specimens.

18 GOST 31384-2017. Protection of concrete and reinforced concrete structures against corrosion. General technical requirements.

19 SP 28.13330-2017. Protection against corrosion of construction.
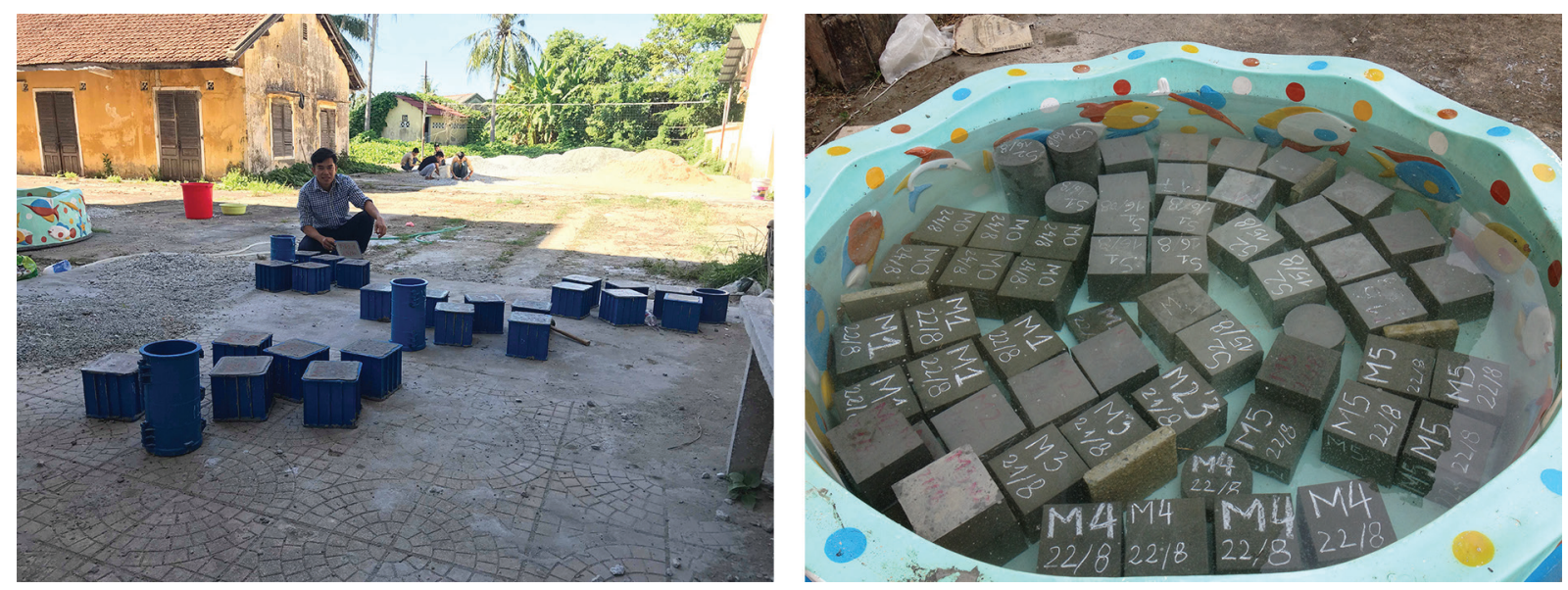

Fig. 1. Specimens were left in the demolding for 24 hours and then submerged in water for curing

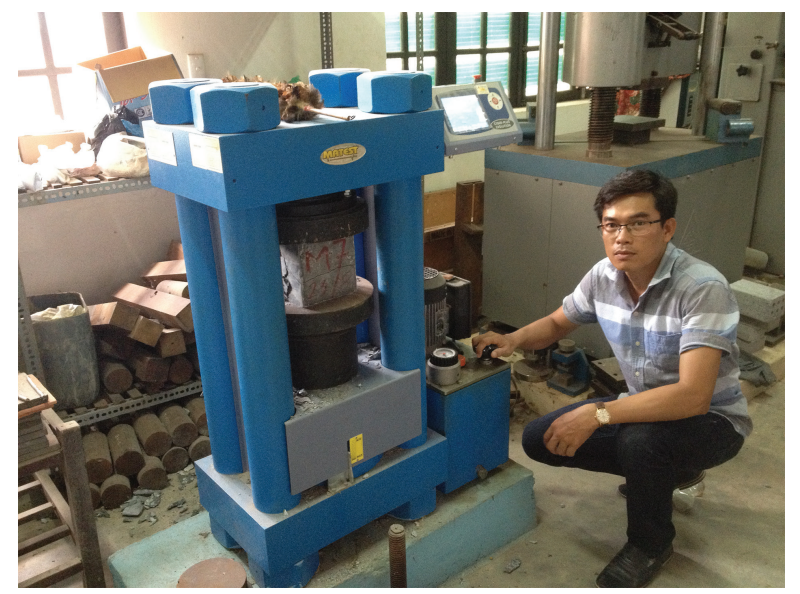

Fig. 2. Specimen testing in Compression testing machine

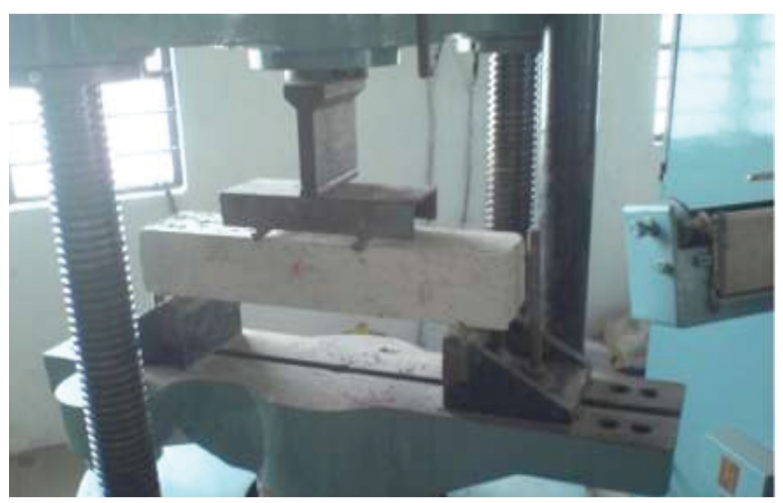

Fig. 3. Testing of prism for flexural strength 
Compression testing machine Matest model C089$17 \mathrm{~N}$ capacity $3000 \mathrm{kN}$ of Italia was used to determine the total compressive load taken by concrete at different ages, such as in fig. 2. This ultimate load divided by the cross-sectional area of the cube $(150 \times 150 \times 150 \mathrm{~mm})$ yields the compressive strength of concrete. The beam specimens of size $100 \times 100 \times 500 \mathrm{~mm}$ were tested in a flexural testing machine of $1000 \mathrm{kN}$ capacity under third-point loading, is shown in fig. 3 .

\section{RESULTS AND DISCUSSION}

Based on the results obtained in this study showed that the strength of concrete is increasing with the addition of admixtures. The MAs mechanical strength seems to be sensitive to the combination in different proportions of SF, FA, and quartz sand flour. This result shows that the optimal dosages of mineral admixtures replacement of cement in HPC mix containing $20 \%$ quartz flour (particles size from 5 to 10 micrometer) replacement of fine aggregate be found at level $40 \%$ (it includes $10 \% \mathrm{SF}+30 \% \mathrm{FA}$ ), results showed compressive/flexure/split tensile strength values are highest. The various tests that are conducted to test the properties of HPC, as follow:

The slump of different concretes was greater than the satisfactory level. It varied from 9.5 to $26.5 \mathrm{~cm}$, as can be seen in table 3 .

Fig. 4. Influence of dosage of quartz powder on compressive strength of HPC

\section{Compressive strength Test on cubes}

The development of compressive strength of HPC mixes at the ages of 3, 7, 28 and 56 days are presented in fig. 4, 5 and table 4. All the mixtures showed that increase strength development with the replacement of cement by silica fume gradually increase range from 0 to $10 \%$ and then decreased at level 12.5 percent. The maximum cube of compressive strength when replacement of cement in HPC mix containing $20 \%$ quartz flour (particles size from 5 to 10 micrometer) replacement of fine aggregate be found at level $10 \%$ SF plus $30 \%$ FA, highest value obtained as $109.73 \mathrm{MPa}$. This result shows the benefit of using FA in combination with SF to produce HPC due to superior mechanical properties, the significant economic savings and It also contributes to reducing environmental pollution.

\section{Splitting tensile strength of HPC}

From the results in table 4 and fig. 3, the split tensile strength of the HPC gradually rises with the raise in the percentage replacement of mineral admixtures and quartz powder, highest split tensile strength value obtained as $6.06 \mathrm{MPa}$ at the age of 28 days when partial replacement of $40 \%$ cement by the mineral admixtures (including FA $30 \%+10 \% \mathrm{SF}$ ) and containing Quartz powder at $20 \%$ (including $10 \%$ size $5 \mu \mathrm{m}$ and $10 \%$ size $10 \mu \mathrm{m}$, the partial replacement of fine aggregate). The results showed $10 \%$ greater split tensile strength than conventional concrete respectively.

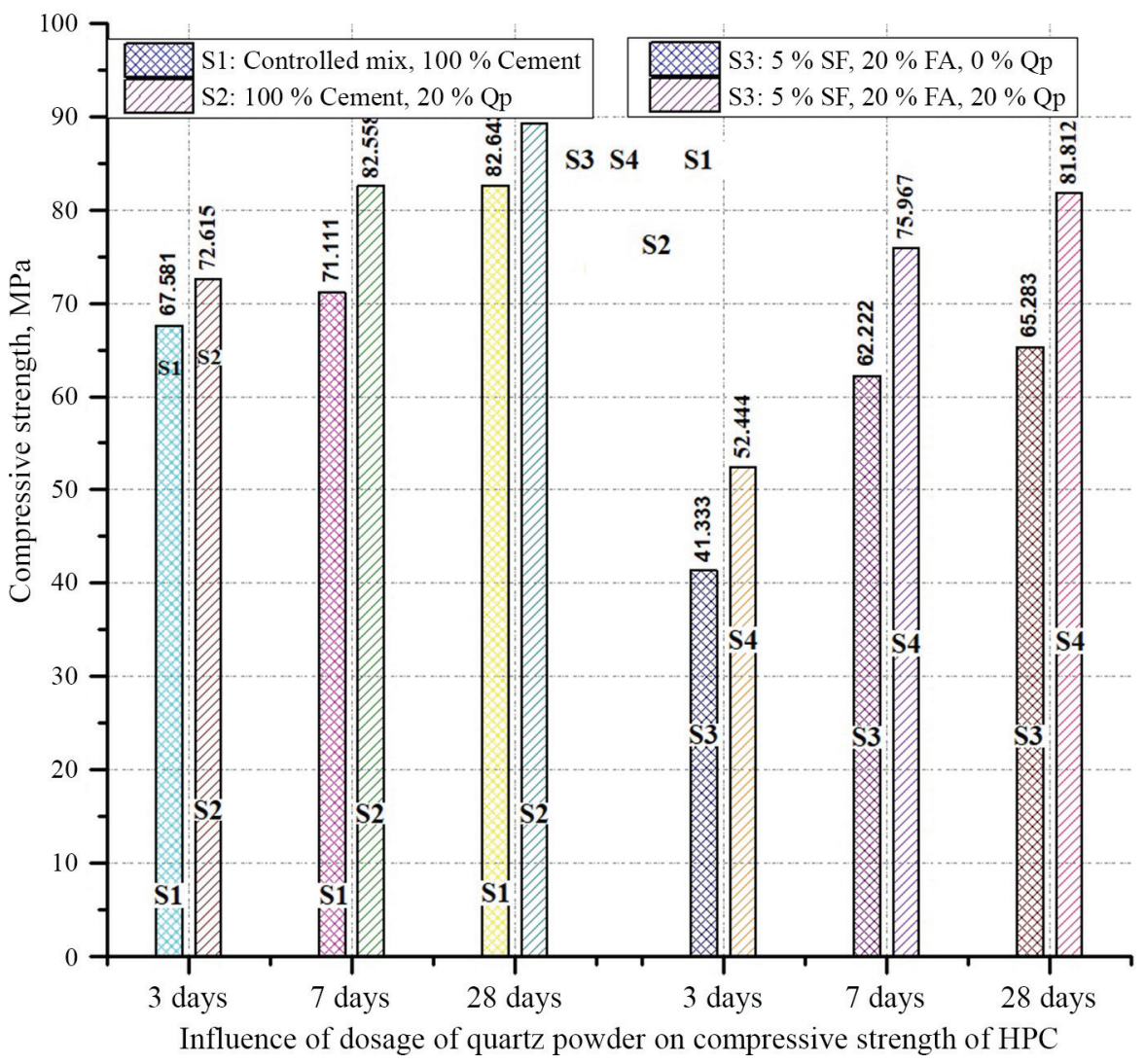




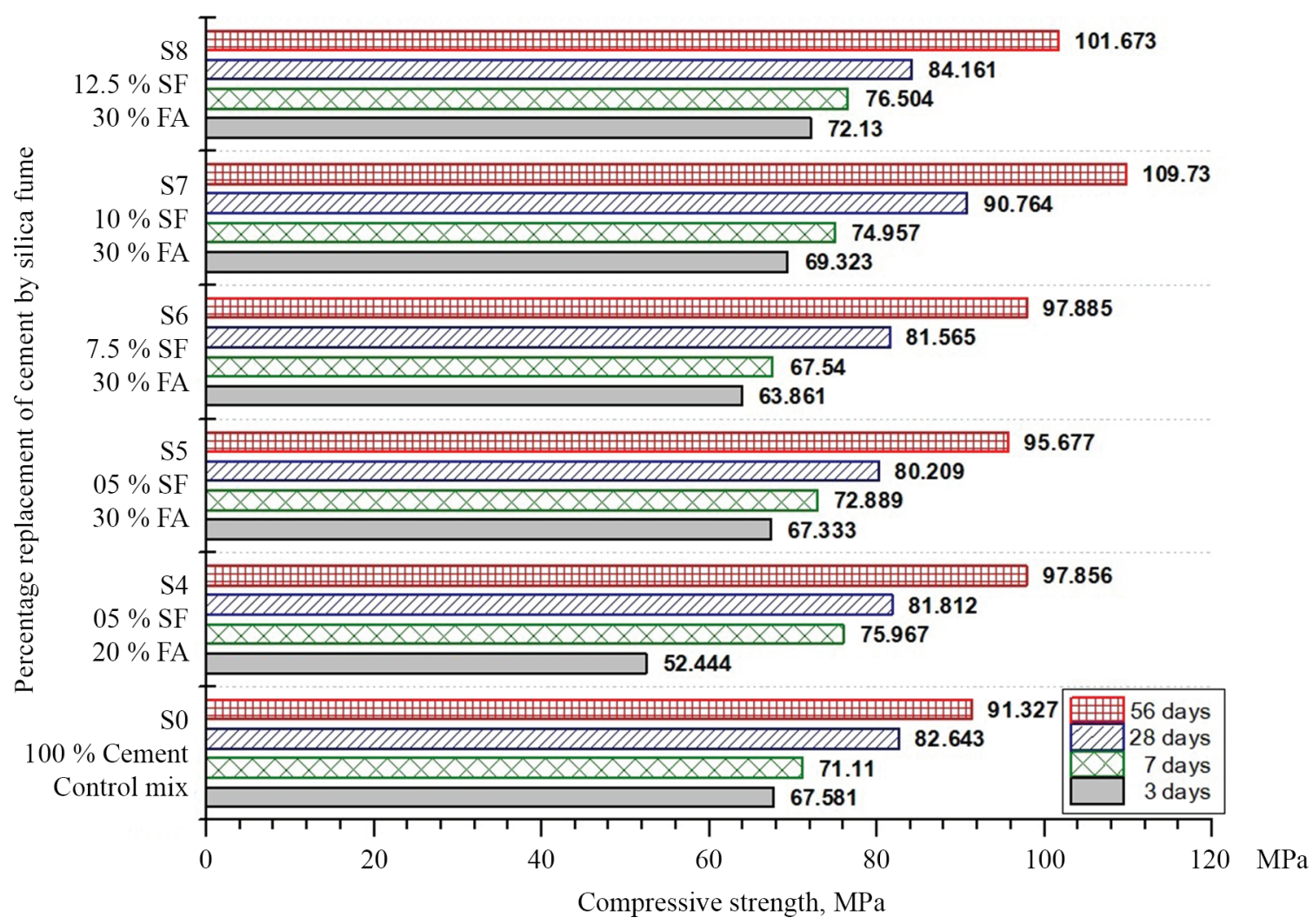

Fig. 5. The compressive strength of HPC with various proportions of mineral admixtures containing Quartz powder

Table 4. Technological properties test result for varying mineral admixtures replacement levels in HPC

\begin{tabular}{|c|c|c|c|c|c|c|c|c|c|c|c|c|c|c|}
\hline \multirow{2}{*}{$\begin{array}{l}\text { Mix } \\
\mathrm{N}^{\circ}\end{array}$} & \multirow{2}{*}{$\begin{array}{l}\text { Binder, } \\
\mathrm{kg} / \mathrm{m}^{3}\end{array}$} & \multirow{2}{*}{$\begin{array}{c}(\mathrm{W}+\mathrm{SP}) \\
/ \mathrm{B}\end{array}$} & \multirow{2}{*}{ Qp } & \multirow{2}{*}{$\begin{array}{l}\text { SF } \\
\\
\%\end{array}$} & \multirow{2}{*}{\begin{tabular}{l|} 
FA \\
$\%$
\end{tabular}} & \multicolumn{4}{|c|}{ Average Concrete Strength, MPa } & \multirow{2}{*}{$\begin{array}{c}\text { Splitting } \\
\text { tensile } \\
\text { strength } \\
f_{c t} \text { at } 28 \\
\text { days, } \\
\text { MPa }\end{array}$} & \multirow{2}{*}{$\begin{array}{c}\text { Flexural } \\
\text { strength } \\
f_{r} \text { at } 28 \\
\text { days, } \\
\text { MPa }\end{array}$} & \multirow{2}{*}{$\begin{array}{c}\text { Perme- } \\
\text { ability } \\
K \text { at } 28 \\
\text { days, } \\
K \cdot 10^{-10} \\
(\mathrm{~cm} / \mathrm{sec})\end{array}$} & \multirow{2}{*}{$\begin{array}{c}\text { Water } \\
\text { absorp- } \\
\text { tion in } 24 \\
\text { hours, } \%\end{array}$} & \multirow{2}{*}{$\begin{array}{c}\text { Abrasion } \\
\text { resis- } \\
\text { tance, } \\
\mathrm{mm}\end{array}$} \\
\hline & & & & & & 3 days & 7 days & 28 days & 56 days & & & & & \\
\hline S1 & \multirow{8}{*}{ 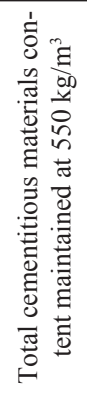 } & \multirow{8}{*}{ 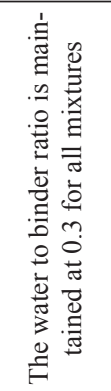 } & - & - & - & 67.581 & 71.111 & 82.643 & 91.327 & 5.65 & 7.848 & 1.57 & 2.49 & 0.84 \\
\hline S2 & & & 20 & - & - & 72.615 & 82.558 & 89.246 & 100.735 & 5.99 & 8.183 & 1.08 & 2.20 & 0.78 \\
\hline S3 & & & - & 5 & 20 & 41.333 & 62.222 & 65.283 & 78.750 & 4.88 & 7. 340 & 4.92 & 3.13 & 1.00 \\
\hline S4 & & & 20 & 5 & 20 & 52.444 & 75.967 & 81.812 & 97.856 & 5.67 & 8.764 & 1.66 & 2.52 & 0.85 \\
\hline S5 & & & 20 & 5 & 30 & 67.333 & 72.889 & 80.209 & 95.677 & 5.59 & 8.314 & 1.86 & 2.57 & 0.87 \\
\hline S6 & & & 20 & 7.5 & 30 & 63.861 & 67.540 & 81.565 & 97.885 & 5.66 & 8.851 & 1.69 & 2.53 & 0.85 \\
\hline S7 & & & 20 & 10 & 30 & 69.323 & 74.957 & 90.764 & 109.730 & 6.06 & 9.336 & 1.03 & 2.19 & 0.77 \\
\hline S8 & & & 20 & 12.5 & 30 & 72.130 & 76.504 & 84.161 & 101.673 & 5.77 & 8.890 & 1.42 & 2.45 & 0.83 \\
\hline
\end{tabular}

\section{Flexural strength of HPC}

From results in table 4 and fig. 3, the flexural strength at the age of 28 days of mineral admixtures concrete continuously increased with respect of controlled mix and reached maximum value of $10 \%$ replacement level. HPC at the age of 28 days with partial replacement of $40 \%$ cement by the mineral admixtures (including FA $30 \%+10 \% \mathrm{SF}$ ) and containing Quartz powder at $20 \%$ (including $10 \%$ size $5 \mu \mathrm{m}$ and $10 \%$ size $10 \mu \mathrm{m}$, the partial replacement of fine aggregate), highest flexural strength value obtained as $9.34 \mathrm{MPa}$, the results showed $12 \%$ greater flexural strength than conventional concrete.

\section{Permeability of HPC}

The permeability of concrete is a key factor influencing the durability of concrete. It is particularly important in reinforced concrete because the concrete must prevent water from reaching the reinforcement. Generally, permeability is defined as "The flow of a fluid through a material under a pressure gradient". This decrease may be due to the fact that concrete permeability is dependent on permeability of each constituent 
material and its geometric arrangement. The permeability of cement paste is primarily related to pore structure, which includes porosity, pore size and connectivity. It was demonstrated that a decrease in the $\mathrm{w} / \mathrm{c}$ ratio is accompanied by lower porosity. A decrease in the porosity means that the there is a decrease in pore size and a disconnection among pores, and so water cannot flow any more through them. Hence, the permeability of concrete decreases accordingly. From result experimental investigation in table 4, a mathematical equation can be used to derive about the relationship between the water permeability and compressive strength $f_{c}^{\prime}$ of concrete was suggested as follows:

$P=\left[5 \cdot 10^{-5} \cdot\left(f_{c}^{\prime}\right)^{2}-0.0934 f_{c}^{\prime}+44.624\right] \cdot 10^{-10}$

for $27 \mathrm{MPa}<f_{c}^{\prime}<110 \mathrm{MPa}$.

Where, $f_{c}^{\prime}$ is the 28-days cube compressive strength, $\mathrm{kg} / \mathrm{cm}^{2}$ of concrete and $P$ is the permeability coefficient, $\mathrm{cm} / \mathrm{sec}$.

\section{Water absorption test}

The amount of water absorbed in a concrete is indicative of its permeable pores, which implies that the steel of concrete shall stain. The addition of mineral admixture to concrete significantly decreases the absorption of water. This is due the transformation of larger pores into finer pores as a result of the filler effect and pozzolanic reaction of silica fume, thus providing a bar- rier against water penetration. From result experimental investigation in table 4, a mathematical equation can be used to derive about the relationship between the water absorption and compressive strength $f_{c}^{\prime}$ of concrete was suggested as follows: $W_{a}=-2.7 \operatorname{Ln}\left(f_{c}^{\prime}\right)+20.73, \%$ for $27 \mathrm{MPa}<f_{c}^{\prime}<110 \mathrm{MPa}$. Where, $f_{c}^{\prime}$ is the 28-days cube compressive strength, $\mathrm{MPa}$, of concrete and $W_{a}$ is the absorption of concrete, $\%$.

\section{Abrasion resistance test}

From result experimental investigation in table 4, a mathematical equation can be used to derive about the relationship between the abrasion resistance and compressive strength $f_{c}^{\prime}$ of concrete, can suggested as follows:

$A_{b}=-2 \cdot 10^{-7} \cdot\left(f_{c}^{\prime}\right)^{2}-6 \cdot 10^{-4} \cdot f_{c}^{\prime}+1.556, \mathrm{~mm}$

for $27 \mathrm{MPa}<f_{c}^{\prime}<110 \mathrm{MPa}$.

Where, $f_{c}^{\prime}$ is the 28-days cube compressive strength, $\mathrm{MPa}$, of concrete and $A_{b}$ is the loss of concrete thickness, mm.

\section{CONCLUSIONS}

Based on the results of the investigation reported in this paper, the following conclusions are made.

This result shows that the optimal dosages of mineral admixtures replacement of cement in HPC mix con-

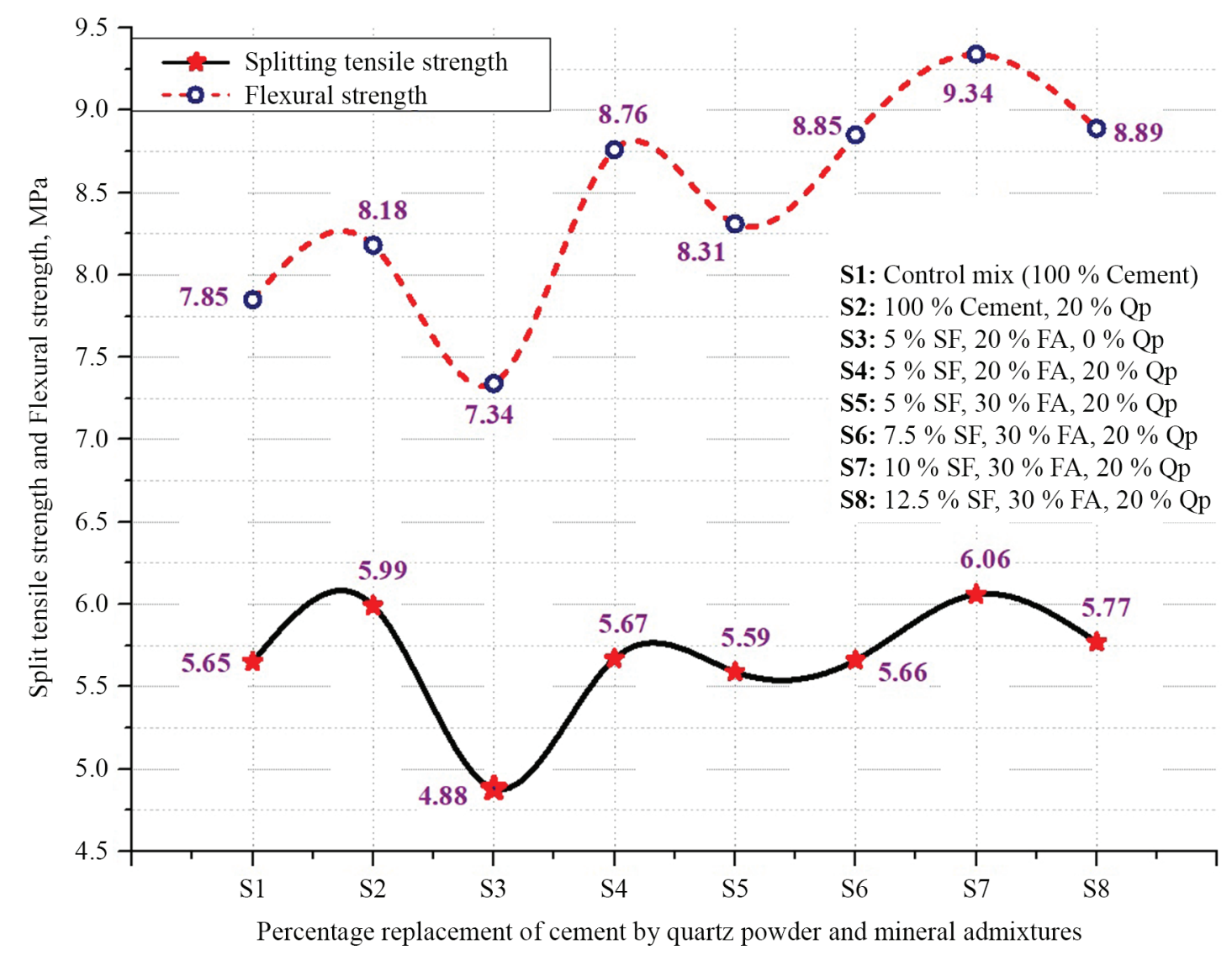

Fig. 6. Split tensile strength and Flexural strength of different HPC mixtures 
taining $20 \%$ quartz flour (with $10 \%$ size $5 \mu \mathrm{m}$ and $10 \%$ size $10 \mu \mathrm{m})$ replacement of fine aggregate be found at level is $40 \%$, into including $30 \%$ FA plus $10 \% \mathrm{SF}$, results showed compressive/flexure/split tensile strength values are highest. The development strength of HPC mixes at the ages of 3, 7, 28 and 56 days are presented in fig. 5, 6 and table 4. All the mixtures showed that increase strength development with the replacement of cement by silica fume gradually increase range from 0 to 10 percent and then decreased at level 12.5 percent while the dosage of fly ash kept constant at level $30 \%$. The percentage of augmenting in the compressive strength about 30 percent at age 56 days, while at the of 28 days split tensile strength augment 10 percent and the flexure strength increased 12 percent.

When materials as quartz powder, silica fume, and fly ash added to the concrete mix leads to the properties of HPC such as water absorption, permeability, sulfate attack resistance, and abrasion resistance are low than compared with conventional concrete. Superplasticizer plays a role very important additives which help to reduce demand water in the mix, but at the time creates the conducive condition for particles aggregate distributed in concrete mixtures. Further, pozzolanic additives (as silica fume, fly ash, etc.) contribute equally important, it very beneficial to gain additional mechanical strength during the further hydration process. The results of the strength and durability related tests have demonstrated superior strength and durability characteristics of HPC mixtures containing quartz powder, fly ash and silica fume. This is due to both physical and chemical effect of it on the concrete mixtures leads to improvement in the microstructure, because of its high pozzolanic nature to form more densely packed C-S-H gel, resulting in fine and discontinuous pore structure.

In addition, from the result of this experimental investigation, a few mathematical equations can be used to derive the durability properties of concrete based on its compressive strength.

High-performance concrete with mineral admixtures can be effectively used in infrastructure construction, such as bridges, road, railway and subway tunnels, the construction of underground works, high rise buildings ... etc, since high early strength and durability in corrosive environment aggressive are required. Moreover, construction costs and period can be reduced.

\section{REFERENCES}

1. Torii K., Kawamura M. Effects of fly ash and silica fume on the resistance of mortar to sulfuric acid and sulfate attack. Cement and Concrete Research. 1994; 24(2):361-370. DOI: 10.1016/0008-8846(94)90063-9

2. Shi Hui-sheng, Xu Bi-wan, Zhou Xiao-chen. Influence of Mineral admixtures on Compressive strength, Gas permeability and Carbonation of High performance concrete. Construction and Building Materials. 2009; 23(5):1980-1985. DOI: 10.1016/j.conbuildmat.2008.08.021

3. Long G., Wang X., Xie Y. Very-high-performance concrete with ultrafine powders. Cement and Concrete Research. 2002; 32(4):601-605. DOI: 10.1016/s0008-8846(01)00732-3

4. Sharfuddin A.M., Kayali O., Anderson W. Chloride penetration in binary and ternary blended cement concretes as measured by two different rapid methods. Cement and Concrete Composites. 2008; 30(7):576-582. DOI: 10.1016/j.cemconcomp.2008.02.005

5. Shannag M.J. Characteristics of lightweight concrete containing mineral admixtures. Construction and Building Materials. 2011; 25(2):658-662. DOI: 10.1016/j.conbuildmat.2010.07.025

6. Dotto J.M.R., Abreu A.G., Dal Molin D.C.C., Muller I.L. Influence of silica fume addition on concretes physical properties and on corrosion behaviour of reinforcement bars. Cement and Concrete Composites. 2004; 26(1):31-39. DOI: 10.1016/S09589465(02)00120-8
7. Kocak Y. A study on the effect of fly ash and silica fume substituted cement paste and mortars. Scientific Research and Essays. 2010; 5(9):990-998. URL: https://academicjournals.org/journal/SRE/article-fulltext-pdf/F4F0F5718906

8. Temiz H., Karakeci A. An investigation on microstructure of cement paste containing fly ash and silica fume. Cement and Concrete Research. 2002; 32(7):1131-1132. DOI: 10.1016/S00088846(02)00749-4

9. Cao J., Chung D.D.L. Microstructural effect of the shrinkage of cement-based materials during hydration, as indicated by electrical resistivity measurement. Cement and Concrete Research. 2004; 34(10):18931897. DOI: 10.1016/j.cemconres.2004.02.002

10. Sounthararajan V.M., Srinivasan K., Sivakumar A. Micro filler effects of silica-fume on the setting and hardened properties of concrete. Research Journal of Applied Sciences, Engineering and Technology. 2013; 6(14):2649-2654. DOI: 10.19026/rjaset.6.3753

11. He Zhimin, Liu Junzhe, Zhu Kangwu. Influence of mineral admixtures on the short and long-term performance of steam-cured concrete. Energy Procedia. 2012; 16(Part B):836-841. DOI: 10.1016/j.egypro.2012.01.134

12. Sadaqat Ullah Khan, Muhammad Fadhil Nuruddin, Tehmina Ayub, Nasir Shafiq. Effects of different mineral admixtures on the properties of fresh concrete. 
The Scientific World Journal. 2014; 2014:1-11. DOI: 10.1155/2014/986567

13. Malathy R., Subramanian K. Role of admixtures in reducing permeability and corrosion of high performance concrete. Civil Engineering \& Construction Review. 2006.

14. Perumal K., Sundararajan R. Effect of partial replacement of cement with silica fume on the strength and durability characteristics of high performance concrete. 29th Conference on our world in Concrete \& Structures, August 2004. Singapore, 2004; 25-26.

15. Amudhavalli N.K., Mathew J. Effect of silica fume on strength and durability parameters of concrete. International Journal of Engineering Sciences \& Emerging Technologies. 2012; 3(1):28-35.

16. Safwan A. Khedr, Mohamed Nagib Abou-Zeid. Characteristics of silica-fume concrete. Journal of Materials in Civil Engineering. 1994; 6(3):357-375. DOI: 10.1061/(ASCE)0899-1561(1994)6:3(357)

17. Sung WonYoo, Seung-Jun Kwon, Sang Hwa Jung. Analysis technique for autogenous shrinkage in high performance concrete with mineral and chemical admixtures. Construction and Building Materials. 2012; 34:1-10. DOI: 10.1016/j.conbuildmat.2012.02.005

18. Salim Barbhuiya, Muneeb Qureshi. Effects of silica fume on the strength and durability properties of concrete. CESDOC 2016

19. Kannan S.U. Experimental investigation on high performance concrete using Silicafume and Flyash. International Journal of Engineering Research and Development. 2017; 13(10):42-49.

20. Tinh hinh va phuong huong tai che, su dung tro xi cua cac nha may nhiet dien o Viet Nam. Vietnam Energy. Vietnam Association of Mineral Processing. 2016. (Situation and direction of recycling, using ash of thermal power plants in Vietnam. Vietnam Energy. Vietnam Association of Mineral Processing. 2016). (Vietnam)

21. Ministry of Industry and Trade (Vietnam), Vietnam Energy. Moi truong nhiet dien than - Hien trang va giai phap (ky 1 va ky 2); Quy hoach cac nha may nhiet dien; Nhiet dien than - Nguon cung cap dien chinh giai doan 2020-2030 ... etc. Vietnam Energy. Ministry of Industry and Trade (Vietnam). (Coal-fired thermal environment — Current situation and solutions (periods 1 and 2); Planning thermal power plants; Coal thermal power - The main power supply source in the period 2020-2030 // Vietnam Energy. Ministry of Industry and Trade (Vietnam)) (Vietnam)

22. Le Van Thien, Ngo Thi Tuong Chau, Le Thi Tham Hong, Le Hoai Nam. Physico-chemical and mineralogical properties of fly ash from thermal power stations in northern Vietnam. VNU Journal of Science: Earth and Environmental Sciences. 2016; 32(1):334-341.

23. Kiran T.G.S., Ratnam M.K.M.V. Fly ash as a partial replacement of cement in concrete and durability study of fly ash in acidic $\left(\mathrm{H}_{2} \mathrm{SO}_{4}\right)$ environment. Interna- tional Journal of Engineering Research and Development. 2014; 10(12):01-13.

24. Galińska A., Czarnecki S. The effect of mineral powders derived from industrial wastes on selected mechanical properties of concrete. Materials Science and Engineering. 2017; 245:032039. DOI: 10.1088/1757899X/245/3/032039

25. Sanjukta Sahoo, Das B.B., Rath A.K., Kar B.B. Acid, alkali and chloride resistance of high-volume fly ash concrete. Indian Journal of Science and Technology. 2015; 8(19). DOI: 10.17485/ijst/2015/v8i19/72266

26. Snellings R., Mertens G., Elsen J. Supplementary Cementitious Materials. Reviews in Mineralogy \& Geochemistry. 2012; 74(1):211-278. DOI: 10.2138/ rmg.2012.74.6

27. Zuquan Jin, Wei Sun, Yunsheng Zhang, Jinyang Jiang, Jianzhong Lai. Cement Concrete Research. 2000; 37(8):1223.

28. Shi C., Stegemann J.A. Acid corrosion resistance of different cementing materials. Cement and Concrete Research. 2000; 30(5):803-808. DOI: 10.1016/ s0008-8846(00)00234-9

29. Chindaprasirt P., Homwuttiwong S., Sirivivatnanon $\mathrm{V}$. Influence of fly ash fineness on strength, drying shrinkage and sulfate resistance of blended cement mortar. Cement and Concrete Research. 2004; 34(7):10871092. DOI: 10.1016/j.cemconres.2003.11.021

30. Chindaprasirt P., Kanchanda P., Sathonsaowaphak A., Cao H.T. Sulfate resistance of blended cements containing fly ash and rice husk ash. Construction and Building Material. 2007; 21(6):1356-1361. DOI: 10.1016/j.conbuildmat.2005.10.005

31. Hameed M.S., Sekar A.S.S. Properties of green concrete containing quarry dust and marble sludge powder as fine aggregate. APRN Journal of Engineering and Applied Sciences. 2009; 4(4):83-89.

32. Bacarji E., Toledo Filho R.D., Koenders E.A.B., Figueiredo E.P., Lopes J.L.M.P. Sustainability perspective of marble and granite residues as concrete fillers. Construction and Building Materials. 2013; 45:1-10. DOI: 10.1016/j.conbuildmat.2013.03.032

33. Megat Johari M.A., Brooks J.J., Shahid Kabir, Patrice Rivard. Influence of supplementary cementitious materials on engineering properties of high strength concrete. Construction and Building Materials. 2011; 25(5):2639-2648. DOI: 10.1016/j.conbuildmat.2010.12.013

34. Moosberg-Bustnes H., Björn Lagerblad, Forssberg E. The function of fillers in concrete. Materials and Structures. 2004; 37(2):74-81. DOI: 10.1007/ BF02486602

35. Courtial M., Noirfontaine M.-N. de, Dunstetter F., Signes-Frehel M., Mounanga P., Cherkaoui K., Khelidj A. Effect of polycarboxylate and crushed quartz in UHPC: Microstructural investigation. Construction and Building Materials. 2013; 44:699-705. DOI: 10.1016/j.conbuildmat.2013.03.077 
36. Rashad A.M., Zeedan S.R. A preliminary study of blended pastes of cement and quartz powder under the effect of elevated temperature. Construction and Building Materials. 2012; 29:672-681. DOI: 10.1016/j. conbuildmat.2011.10.006

37. Yang Q., Zhang S., Huang S., He Y. Effect of ground quartz sand on properties of high-strength concrete in the steam-autoclaved curing. Cement and Concrete Research. 2000; 30(12):1993-1998. DOI: 10.1016/ S0008-8846(00)00395-1

38. Marinoni N., Broekmans A.T.M.M. Microstructure of selected aggregate quartz by XRD, and a critical review of the crystallinity index. Cement and
Concrete Research. 2013; 54:215-225. DOI: 10.1016/j. cemconres.2013.08.007

39. Pustovgar A.P., Ivanova I.S., Elenova A.A., Abramova A.Yu., Adamtsevich A.O. Influence of quartz flour on technological properties of self-completed concrete mixtures. Proceedings of the Moscow State University of Civil Engineering. 2018; 13:6(117):717-728. DOI: 10.22227/1997-0935.2018.6.717-728 (rus.).

40. Pustovgar A.P., Ivanova I.S., Medvedev V.V., Adamtsevich A.O. The use of silverbond quartz flour in the design of self-compacting concrete compositions. Materials technology of concrete. 2018; 5-6:1014. (rus.).

Received October 27, 2018.

Adopted in a revised form on November 9, 2018.

Approved for publication December 27, 2018.

A в о т т те a th or s: Nguyen Duc Vinh Quang - Postgraduate student of Department of Technologies of Cohesive Materials and Concretes, Moscow State University of Civil Engineering (National Research University) (MGSU), 26 Yaroslavskoe shosse, 129337, Russian Federation, ndvquang@hueic.edu.vn;

Yuriy M. Bazhenov - Doctor of Technical Sciences, Professor, Head of the Department of Technologies of Cohesive Materials and Concretes, Moscow State University of Civil Engineering (National Research University) (MGSU), 26 Yaroslavskoe shosse, Russian Federation, 129337, Russian Federation, zavkaf@list.ru;

Olga V. Aleksandrova - Candidate of Technical Sciences, Associate Professor, Associate Professor of Department of Technologies of Cohesive Materials and Concretes, Moscow State University of Civil Engineering (National Research University) (MGSU), 26 Yaroslavskoe shosse, 129337, Russian Federation, aleks_olvl@mail.ru.

\section{ЛИТЕРАТУРА}

1. Torii K., Kawamura M. Effects of fly ash and silica fume on the resistance of mortar to sulfuric acid and sulfate attack // Cement and Concrete Research. 1994. Vol. 24. Issue 2. Pp. 361-370. DOI: 10.1016/0008-8846(94)90063-9

2. Shi Hui-sheng Xu, Bi-wan Zhou, Xiao-chen. Influence of mineral admixtures on compressive strength, gas permeability and carbonation of high performance concrete // Construction and Building Materials. 2009. Vol. 23. Issue 5. Pp. 1980-1985. DOI: 10.1016/j.conbuildmat.2008.08.021

3. Long G., Wang X., Xie Y. Very-high-performance concrete with ultrafine powders // Cement and Concrete Research. 2002. Vol. 32. Issue 4. Pp. 601-605. DOI: 10.1016/s0008-8846(01)00732-3

4. Sharfuddin Ahmed M., Kayali O., Anderson W. Chloride penetration in binary and ternary blended cement concretes as measured by two different rapid methods // Cement and Concrete Composites. 2008. Vol. 30. Issue 7. Pp. 576-582. DOI: 10.1016/j. cemconcomp.2008.02.005

5. Shannag M.J. Characteristics of lightweight concrete containing mineral admixtures // Construction and Building Materials. 2011. Vol. 25. Issue 2. Pp. 658662. DOI: 10.1016/j.conbuildmat.2010.07.025
6. Dotto J.M.R., Abreu A.G., Dal Molin D.C.C., Muller I.L. Influence of silica fume addition on concretes physical properties and on corrosion behaviour of reinforcement bars // Cement and Concrete Composites. 2004. Vol. 26. Issue 1. Pp. 31-39. DOI: 10.1016/S09589465(02)00120-8

7. Kocak $Y$. A study on the effect of fly ash and silica fume substituted cement paste and mortars // Scientific Research and Essays. 2010. Vol. 5 (9). Pp. 990-998. URL: https://academicjournals.org/journal/SRE/articlefull-text-pdf/F4F0F5718906

8. Temiz H., Karakeci A. An investigation on microstructure of cement paste containing fly ash and silica fume // Cement and Concrete Research. 2002. Vol. 32. Issue 7. Pp. 1131-1132. DOI: 10.1016/S00088846(02)00749-4

9. Cao J., Chung D.D.L. Microstructural effect of the shrinkage of cement-based materials during hydration, as indicated by electrical resistivity measurement // Cement and Concrete Research. 2004. Vol. 34. Issue 10. Pp. 1893-1897. DOI: 10.1016/j. cemconres.2004.02.002

10. Sounthararajan V.M., Srinivasan K., Sivakumar A. Micro filler effects of silica-fume on the setting and hardened properties of concrete // Research 
Journal of Applied Sciences, Engineering and Technology. 2013. Vol. 6. Issue 14. Pp. 2649-2654. DOI: $10.19026 /$ rjaset.6.3753

11. He Zhimin, Liu Junzhe, Zhu Kangwu. Influence of mineral admixtures on the short and longterm performance of steam-cured concrete // Energy Procedia. 2012. Vol. 16. Part B. Pp. 836-841. DOI: 10.1016/j.egypro.2012.01.134

12. Sadaqat Ullah Khan, Muhammad Fadhil Nuruddin, Tehmina Ayub, Nasir Shafiq. Effects of different mineral admixtures on the properties of fresh concrete // The Scientific World Journal. 2014. Vol. 2014. Pp. 1-11. DOI: 10.1155/2014/986567

13. Malathy R., Subramanian K. Role of admixtures in reducing permeability and corrosion of high performance concrete // Civil Engineering \& Construction Review. 2006.

14. Perumal K., Sundararajan R. Effect of partial replacement of cement with silica fume on the strength and durability characteristics of high-performance concrete // 29th Conference on our world in Concrete \& Structures. Singapore. 2004. Pp. 25-26.

15. Amudhavalli N.K., Mathew J. Effect of silica fume on strength and durability parameters of concrete // International Journal of Engineering Sciences \& Emerging Technologies. 2012. Vol. 3. Issue 1. Pp. 28-35.

16. Safwan A. Khedr, Mohamed Nagib Abou-Zeid. Characteristics of silica-fume concrete // Journal of Materials in Civil Engineering. 1994. Vol. 6. Issue 3. Pp. 357-375. DOI: 10.1061/ (ASCE)0899-1561(1994)6:3(357)

17. Sung WonYoo, Seung-Jun Kwon, Sang Hwa Jung. Analysis Technique for Autogenous Shrinkage in High Performance Concrete with Mineral and Chemical Admixtures // Construction and Building Materials. 2012. Vol. 34. Pp. 1-10.

18. Salim Barbhuiya, Muneeb Qureshi. Effects of silica fume on the strength and durability properties of concrete // CESDOC 2016.

19. Kannan S.U. Experimental investigation on high performance concrete using silicafume and flyash // International Journal of Engineering Research and Development. 2017. Vol. 13. Issue 10. Pp. 42-49.

20. Tinh hinh va phuong huong tai che, su dung tro xi cua cac nha may nhiet dien o Viet Nam // Vietnam Energy. Vietnam Association of Mineral Processing. 2016s. URL: http://nangluongvietnam.vn/news/vn/ khoa-hoc-va-cong-nghe/tinh-hinh-va-phuong-huongtai-che-su-dung-tro-xi-cua-cac-nha-may-nhiet-dien-oviet-nam.html. (Ситуация и направление утилизации с использованием золы тепловых электростанций во Вьетнаме // Vietnam Energy. Vietnam Association of Mineral Processing. 2016.)

21. Moi truong nhiet dien than - Hien trang va giai phap (ky 1 va ky 2); Quy hoach cac nha may nhiet dien; Nhiet dien than - Nguon cung cap dien chinh giai doan 2020-2030 ... etc. // Vietnam Energy. Ministry of
Industry and Trade (Vietnam). URL: http://nangluongvietnam.vn/news/vn/bao-ton-nang-luong/moi-truong-nhiet-dien-than-hien-trang-va-giai-phap-ky-1.html (Угольная тепловая среда: реальные ситуации и решения [№ 1 и 2]; Планирование тепловых электростанций. Угольная тепловая электростанция - основное электроснабжение в период 2020-2030 гг. // Vietnam Energy. Ministry of Industry and Trade (Vietnam))

22. Le Van Thien, Ngo Thi Tuong Chau, Le Thi Tham Hong, Le Hoai Nam. Physico-chemical and Mineralogical Properties of Fly Ash from Thermal Power Stations in Northern Vietnam // VNU Journal of Science: Earth and Environmental Sciences. 2016. Vol. 32. No. 1. Pp. 334-341.

23. Kiran T.G.S., Ratnam M.K.M.V. Fly ash as a partial replacement of cement in concrete and durability study of fly ash in acidic $\left(\mathrm{H}_{2} \mathrm{SO}_{4}\right)$ environment // International Journal of Engineering Research and Development. 2014. Vol. 10. Issue 12. Pp. 01-13.

24. Galińska A., Czarnecki S. The effect of mineral powders derived from industrial wastes on selected mechanical properties of concrete // Materials Science and Engineering. 2017. Vol. 245. P. 032039. DOI: 10.1088/1757-899X/245/3/032039

25. Sanjukta Sahoo, Das B.B., Rath A.K., Kar B.B. Acid, Alkali and chloride resistance of high volume fly ash concrete // Indian Journal of Science and Technology. 2015. Vol. 8 (19). DOI: 10.17485/ijst/2015/ v8i19/72266

26. Snellings R., Mertens G., Elsen J. Supplementary cementitious materials // Reviews in Mineralogy \& Geochemistry. 2012. Vol. 74. Issue 1. Pp. 211-278. DOI: $10.2138 / \mathrm{rmg} .2012 .74 .6$

27. Zuquan Jin, Wei Sun, Yunsheng Zhang, Jinyang Jiang, Jianzhong Lai. Cement concrete research. 2000. Vol. 37. Issue 8. P. 1223.

28. Shi C., Stegemann J.A. Acid corrosion resistance of different cementing materials // Cement and Concrete Research. 2000. Vol. 30. Issue 5. Pp. 803-808. DOI: $10.1016 / \mathrm{s} 0008-8846(00) 00234-9$

29. Chindaprasirt P., Homwuttiwong S., Sirivivatnanon $V$. Influence of fly ash fineness on strength, drying shrinkage and sulfate resistance of blended cement mortar // Cement and Concrete Research. 2004. Vol. 34. Issue 7. Pp. 1087-1092. DOI: 10.1016/j.cemconres.2003.11.021

30. Chindaprasirt P., Kanchanda P., Sathonsaowaphak A., Cao H.T. Sulfate resistance of blended cements containing fly ash and rice husk ash // Construction and Building Material. 2007. Vol. 21. Issue 6. Pp. 13561361. DOI: 10.1016/j.conbuildmat.2005.10.005

31. Hameed M.S., Sekar A.S.S. Properties of green concrete containing quarry dust and marble sludge powder as fine aggregate // APRN Journal of Engineering and Applied Sciences. 2009. Vol. 4. Issue 4. Pp. 83-89.

32. Bacarji E., Toledo Filho R.D., Koenders E.A.B., Figueiredo E.P., Lopes J.L. Sustain- 
ability perspective of marble and granite residues as concrete fillers // Construction and Building Materials. 2013. Vol. 45. Pp. 1-10. DOI: 10.1016/j.conbuildmat.2013.03.032

33. Megat Johari M.A., Brooks J.J., Kabir S., Rivard $P$. Influence of supplementary cementitious materials on engineering properties of high strength concrete // Construction and Building Materials. 2011. Vol. 25. Issue 5. Pp. 2639-2648. DOI: 10.1016/j.conbuildmat.2010.12.013

34. Moosberg-Bustnes M., Lagerblad B., Forssberg $E$. The function of fillers in concrete // Materials and Structures. 2004. Vol. 37. Issue 2. Pp. 74-81. DOI: $10.1007 / \mathrm{bf0} 2486602$

35. Courtial M., Noirfontaine M.-N. de, Dunstetter F., Signes-Frehel M., Mounanga P., Cherkaoui K., Khelidj $A$. Effect of polycarboxylate and crushed quartz in UHPC: Microstructural investigation // Construction and Building Materials. 2013. Vol. 44. Pp. 699-705. DOI: 10.1016/j.conbuildmat.2013.03.077

36. Rashad A.M., Zeedan S.R. A preliminary study of blended pastes of cement and quartz powder under the effect of elevated temperature // Construction and
Building Materials. 2011. Vol. 29. Pp. 672-681. DOI: 10.1016/j.conbuildmat.2011.10.006

37. Yang Q., Zhang S., Huang S., He Y. Effect of ground quartz sand on properties of high-strength concrete in the steam-autoclaved curing // Cement and Concrete Research. 2000. Vol. 30. Issue 12. Pp. 1993-1998. DOI: $10.1016 / \mathrm{S} 0008-8846(00) 00395-1$

38. Marinoni N., Broekmans A.T.M.M. Microstructure of selected aggregate quartz by XRD, and a critical review of the crystallinity index // Cement and Concrete Research. 2013. Vol. 54. Pp. 215-225. DOI: 10.1016/j. cemconres.2013.08.007

39. Пустовгар А.П., Иванова И.С., Еленова А.А., Абрамова А.Ю., Адамцевич А.О. Влияние кварцевой муки на технологические свойства самоуплотняющихся бетонных смесей // Вестник МГСУ. 2018. T. 13. Вып. 6 (117). C. 717-728. DOI: 10.22227/19970935.2018.6.717-728

40. Пустовгар А.П., Иванова И.С., Медведев В.В., Адамцевич А.О. Применение кварцевой муки silverbond в проектировании составов самоуплотняющихся бетонов // Материалы технологии бетонов. 2018. № 5-6. С. 10-14.

Поступила в редакциию 27 октября 2018 г.

Принята в доработанном виде 9 ноября 2018 г.

Одобрена для публикащии 27 декабря 2018 г.

О в А в т о А Х: Нгуен Дык Винь Куанг - аспирант кафедры технологии вяжущих веществ и бетонов, Национальный исследовательский Московский государственный строительный университет (НИУ МГСУ), 129337, г. Москва, Ярославское шоссе, д. 26, ndvquang@hueic.edu.vn;

Баженов Юрий Михайлович - доктор технических наук, профессор, профессор кафедры технологии вяжущих веществ и бетонов, заведующий кафедрой технологии вяжущих веществ и бетонов, Национальный исследовательский Московский государственный строительный университет (НИУ МГСУ), 129337, г. Москва, Ярославское шоссе, д. 26, zavkaf@list.ru;

Александрова Ольга Владимировна - кандидат технических наук, доцент, доцент кафедры технологии вяжущих веществ и бетонов, Национальный исследовательский Московский государственный строительный университет (НИУ МГСУ), 129337, г. Москва, Ярославское шоссе, д. 26, aleks_olv1@mail.ru. 